\title{
STUDI KOMPARASI ANTARA STRATEGI QUIP DAN STRATEGI INFORMATION CHARTS DALAM PEMBELAJARAN MENULIS TEKS EKSPOSISI
}

\author{
Ayu Wulandari \\ ION International Education Yogyakarta \\ email: ayu_bahasa@yahoo.co.id
}

\begin{abstract}
ABSTRAK
Penelitian ini bertujuan untuk mengetahui perbedaan antara strategi QUIP (Questions into Paragraphs) dan strategi Information Charts dalam pembelajaran menulis teks eksposisi. Jenis penelitian ini adalah eksperimen semu dengan desain Randomized Pretest-Posttest Control Group Design. Hasil penelitian menunjukkan bahwa (1) terdapat perbedaan yang signifikan antara keterampilan menulis teks eksposisi siswa yang diajar menggunakan strategi QUIP dengan siswa yang tidak diajar menggunakan strategi QUIP. (2) Penggunaan strategi QUIP dalam pembelajaran menulis teks eksposisi lebih efektif apabila dibandingkan dengan pembelajaran menulis teks eksposisi tanpa strategi QUIP. (3) Terdapat perbedaan yang signifikan antara keterampilan menulis teks eksposisi siswa yang diajar menggunakan strategi Information Charts dengan siswa yang tidak diajar menggunakan strategi Information Charts. (4) Penggunaan strategi Information Charts dalam pembelajaran menulis teks eksposisi lebih efektif apabila dibandingkan dengan pembelajaran menulis teks eksposisi tanpa strategi Information Charts. (5) Terdapat perbedaan yang signifikan antara keterampilan menulis teks eksposisi siswa yang diajar menggunakan strategi QUIP dengan siswa yang diajar menggunakan strategi Information Charts. (6) Penggunaan strategi QUIP lebih efektif apabila dibandingkan dengan strategi Information Charts dan strategi konvensional dalam pembelajaran menulis teks eksposisi.
\end{abstract}

Kata Kunci: strategi QUIP (questions into paragraphs), strategi information charts, dan kemampuan menulis teks eksposisi

\section{A COMPARATIVE STUDY BETWEEN QUIP) STRATEGY AND INFORMATION CHARTS STRATEGY IN LEARNING OF AN EXPOSITION TEXT WRITING}

\begin{abstract}
This research has a purpose to know the differences between QUIP (Questions into Paragraphs) strategy and Information Charts strategy in learning exposition text writing on the seventh grade of SMPs in Yogyakarta. The type of this research is a quasi experiment with Randomized Pretest-Posttest Control Group Design. The results show that (1) there is a significant difference between the student's ability of the exposition text writing which is taught by using QUIP strategy and the students which are not taught by using QUIP strategy. (2) The use of QUIP strategy in the learning of exposition text writing is more effective than without QUIP strategy. (3) There is a significant difference between the student's ability of an exposition text writing which is taught by QUIP strategy and the students which are not. (4) The use of Information Charts strategy in the learning of an exposition text writing is more effective than without using the Information Charts strategy. (5) There is a significant difference between the student's ability of an exposition text writing using QUIP strategy with the students which are taught by using Information Charts strategy. (6) The use of QUIP strategy is more effective than Information Charts and conventional strategy in learning of an exposition text writing on the seventh grade of SMPs in Yogyakarta.
\end{abstract}

Keywords: QUIP (questions into paragraphs) strategy, information charts strategy, and the ability of an exposition text writing 


\section{PENDAHULUAN}

Menulis merupakan salah satu kemampuan yang paling akhir dikuasai oleh siswa setelah kemampuan mendengarkan, berbicara, dan membaca. Zainurrahman (2011: 2) mengemukakan bahwa menulis merupakan keterampilan yang tidak dimiliki oleh semua orang. Dalam menulis, diperlukan latihan untuk mencapai predikat "mampu menulis dengan baik dan benar".

Dewasa ini, kemampuan menulis siswa Indonesia ditengarai masih dalam kategori rendah. Dalam media online Kompas (2011) Abdul Khak, Kepala Balai Bahasa Bandung mengemukakan bahwa tradisi menulis di Indonesia jauh lebih rendah dibandingkan dengan tradisi membaca. Rendahnya kemampuan menulis akibat dari rendahnya minat baca. Akar penyebab rendahnya kemampuan menulis pemuda saat ini adalah kurikulum pendidikan yang tidak menganggap pembelajaran membaca dan menulis sebagai pelajaran penting.

Lebih lanjut, disebutkan bahwa rendahnya kemampuan menulis juga disebabkan oleh guru bahasa itu sendiri. Para guru lebih disibukkan dengan pembuatan bahan pelajaran, lembaran evaluasi siswa, pelatihan ini itu, pada akhir-akhir tahun pelajaran direpotkan dengan les tambahan untuk pemantapan nilai bahasa Indonesia para siswa, apabila tidak mau sekolah mereka tercoreng namanya gara-gara banyak siswanya tidak lulus UN (Efendi, 2011).

Negara seperti Selandia Baru, Jepang, Korea Selatan, Jerman, dan beberapa negara maju lainnya, bahkan di Selandia Baru, yang merupakan salah satu sistem pendidikan terbaik di dunia, mewajibkan pelajaran membaca dan menulis sekitar 50 persen dari seluruh jam pelajaran. Bandingkan dengan negara Indonesia, yang hanya fokus pada nilai UN yang lebih dari 5,5 (Efendi, 2011).

Berdasarkan survei awal yang dilakukan, rendahnya kemampuan menulis siswa disebabkan pula oleh proses pembelajaran di kelas meliputi media pembelajaan dan strategi pembelajaran yang kurang menarik antusias siswa untuk menulis. Banyaknya tugas-tugas siswa pun memungkinkan adanya peluang siswa tidak memiliki banyak waktu untuk menulis dan pada akhirnya siswa hanya menjiplak dari media online internet.

Penelitian-penelitian terdahulu mengenai keterampilan menulis menunjukkan bahwa kemampuan menulis penting untuk diperhatikan. Damayanti (2010) dalam penelitiannya berjudul "Keefektifan penggunaan siaran TV dan radio dalam pembelajaran keterampilan menulis berita peserta didik SMP", menyebutkan bahwa terjadi permasalahan dalam keterampilan menulis, di antaranya adalah media pembelajaran yang digunakan oleh guru kurang bervariasi, dalam pembelajaran guru lebih menitikberatkan pada aspek pengetahuan atau kaidah bahasa.

Selain itu, penerapan kurikulum 2013 dalam mata pelajaran bahasa Indonesia menekankan pada pembelajaran berbasis teks. Terdapat beraneka ragam jenis teks yang dapat siswa pelajari, khususnya pada jenjang SMP. Aneka jenis teks yang dipelajari pada jenjang SMP khususnya kelas VII yakni, teks laporan hasil observasi, deskriptif, eksposisi, eksplanasi, dan teks cerpen.

Penelitian ini memfokuskan pada pembelajaran menulis teks eksposisi. Teks eksposisi ini, pada kurikulum KTSP diterapkan di kelas X SMA, namun pada kurikulum 2013 teks eksposisi sudah diperkenalkan dan diajarkan untuk siswa kelas VII SMP sehingga ini menjadi tantangan tersendiri untuk guru bagaimana mengajarkannya kepada siswa karena teks eksposisi merupakan teks yang paling sulit dan membutuhkan kemampuan untuk berpikir kritis.

Permasalahan-permasalahan tersebut, tentunya dapat teratasi apabila guru menerapkan strategi pembelajaran yang sesuai diterapkan dalam pembelajaran menulis, khususnya menulis teks eksposisi. Salah satu strategi yang dapat diterapkan adalah strategi QUIP (Questions into Paragrahps) atau strategi Pertanyaan menjadi Paragraf. Strategi ini membantu siswa dalam menulis teks eksposisi. Terdapat tiga langkah utama yang terstruktur yakni, interview grid, outline, dan paragraphs. Strategi lain yang dapat diterapkan adalah strategi Information Charts. Dalam strategi ini, siswa diinstruksikan untuk berpikir secara kritis. Kedua strategi ini tentunya memiliki karakteristik masing-masing yang menjadi pembeda di antara keduanya. 
Berdasarkan survei awal yang dilakukan di SMP Negeri 1 Yogyakarta dan SMP Negeri 5 Yogyakarta, penerapan strategi QUIP (Questions into Paragraphs) dan Information Charts belum pernah dilakukan. Sekali pun banyak penelitian terdahulu yang meneliti tentang strategi dalam menulis teks eksposisi, namun belum ditemukan penelitian untuk membandingkan antara strategi QUIP (Questions Into Paragraphs) dan strategi Information Charts dalam pembelajaran menulis teks eksposisi siswa kelas VII SMP Se-Kota Yogyakarta. Selain itu, belum diketahui bagaimana tingkat keefektifan kedua strategi tersebut sehingga penelitian ini perlu dilakukan. Melalui penelitian ini, diharapkan perbedaan kemampuan menulis teks eksposisi antara siswa yang diajar menggunakan strategi QUIP (Questions Into Paragraphs) dan strategi Information Charts dengan siswa yang diajar tanpa menggunakan kedua strategi tersebut dapat ditemukan.

Berdasarkan latar belakang masalah yang telah dikemukakan tersebut, dapat diidentifikasi permasalahan yang muncul, yakni: (1) rendahnya kemampuan menulis siswa kelas VII SMP Se-Kota Yogyakarta. (2) Media pembelajaran menulis teks eksposisi siswa kelas VII SMP Se-Kota Yogyakarta kurang bervariasi. (3) Strategi pembelajaran menulis teks eksposisi siswa kelas VII SMP Se-Kota Yogyakarta kurang bervariasi dan efektif digunakan. (4) Teks eksposisi merupakan teks yang paling sulit dipelajari dalam kurikulum 2013. (5) Kurangnya waktu yang dibutuhkan siswa kelas VII SMP Se-Kota Yogyakarta untuk menulis. (6) Belum diketahui tingkat keefektifan strategi QUIP (Questions Into Paragraphs) dalam pembelajaran menulis teks eksposisi siswa kelas VII SMP Se-Kota Yogyakarta. (7) Belum diketahui tingkat keefektifan strategi Information Charts dalam pembelajaran menulis teks eksposisi siswa kelas VII SMP Se-Kota Yogyakarta. (8) Strategi pembelajaran QUIP (Questions Into Paragraphs) dan Information Charts belum pernah diterapkan di SMP Kota Yogyakarta.

Agar permasalahan yang akan dibahas terpusat, masalah yang diteliti dalam penelitian ini dibatasi pada strategi QUIP (Questions into Paragraphs) dan strategi Information Charts dalam pembelajaran menulis teks eksposisi.
Strategi QUIP (Questions into Paragraphs) merupakan strategi yang menggunakan wawancara dan buku/artikel sebagai sumber referensi dan strategi Information Charts adalah strategi yang hanya menggunakan buku/artikel sebagai sumber referensi. Kedua strategi tersebut digunakan dalam pembelajaran menulis teks eksposisi. Dengan demikian, akan diketahui perbedaan dan keefektifan dari keduanya dalam pembelajaran menulis teks eksposisi siswa kelas VII SMP Se-Kota Yogyakarta.

Berdasarkan pembatasan masalah tersebut, ditentukan rumusan masalah penelitian ini, yakni: (1) Apakah terdapat perbedaan yang signifikan antara keterampilan menulis teks eksposisi siswa yang diajar menggunakan strategi QUIP (Questions into Paragrahps) dengan siswa yang tidak diajar menggunakan strategi QUIP (Questions into Paragrahps)?; (2) Apakah penggunaan strategi QUIP (Questions into Paragrahps) efektif digunakan dalam pembelajaran menulis teks eksposisi siswa kelas VII SMP Se-Kota Yogyakarta?; (3) Apakah terdapat perbedaan yang signifikan antara keterampilan menulis teks eksposisi siswa yang diajar menggunakan strategi Information Charts dengan siswa yang tidak diajar menggunakan strategi Information Charts?; (4) Apakah penggunaan strategi Information Charts efektif digunakan dalam pembelajaran menulis teks eksposisi siswa kelas VII SMP Se-Kota Yogyakarta?; (5) Apakah terdapat perbedaan yang signifikan antara keterampilan menulis teks eksposisi siswa yang diajar menggunakan strategi QUIP (Questions into Paragrahps) dengan siswa yang diajar menggunakan strategi Information Charts?; dan (6) Apakah penggunaan strategi QUIP (Questions into Paragraphs) lebih efektif apabila dibandingkan dengan strategi information charts dan strategi konvensional dalam pembelajaran menulis teks eksposisi siswa kelas VII SMP Se-Kota Yogyakarta?

Tujuan yang hendak dicapai dalam penelitian ini yakni: (1) Untuk membuktikan ada tidaknya perbedaan yang signifikan antara keterampilan menulis teks eksposisi siswa yang diajar menggunakan strategi QUIP (Questions into Paragrahps) dengan siswa yang tidak diajar menggunakan strategi QUIP (Questions into Paragrahps). (2) Untuk membuktikan 
keefektifan penggunaan strategi QUIP (Questions into Paragrahps) dalam pembelajaran menulis teks eksposisi siswa kelas VII SMP SeKota Yogyakarta. (3) Untuk membuktikan ada tidaknya perbedaan antara keterampilan menulis teks eksposisi siswa yang diajar menggunakan strategi Information Charts dengan siswa yang tidak diajar menggunakan strategi Information Charts. (4) Untuk membuktikan keefektifan penggunaan strategi Information Charts dalam pembelajaran menulis teks eksposisi siswa kelas VII SMP Se-Kota Yogyakarta. (5) Untuk membuktikan perbedaan yang signifikan antara keterampilan menulis teks eksposisi siswa yang diajar menggunakan strategi QUIP (Questions into Paragrahps) dengan siswa yang diajar menggunakan strategi Information Charts. (6) Untuk membuktikan penggunaan strategi QUIP (Questions into Paragraphs) lebih efektif apabila dibandingkan dengan strategi information charts dan strategi konvensional dalam pembelajaran menulis teks eksposisi siswa kelas VII SMP Se-Kota Yogyakarta.

\section{METODE}

Penelitian ini menggunakan pendekatan kuantitatif eksperimen semu dengan desain Randomized Pretest-Posttest Control Group Design yang dikembangkan dengan dua kelas eksperimen dan satu kelas kontrol. Kelompok eksperimen dalam penelitian ini adalah kelompok yang menggunakan strategi QUIP (Questions into Paragraphs) dan strategi Information Charts. Kelompok kontrol adalah kelompok yang tidak menggunakan strategi QUIP (Questions Into Paragraphs) dan Information Charts. Dengan demikian, kelompok kontrol dalam penelitian ini adalah kelompok yang menggunakan pembelajaran konvensional atau pembelajaran sehari-hari yang disesuaikan dengan kebiasaan guru mengajar.

Penelitian ini dilaksanakan di dua SMP yang ada di Kota Yogyakarta, yaitu SMP Negeri 1 Yogyakarta dan SMP Negeri 5 Yogyakarta. Alasan pemilihan sekolah tersebut sebagai lokasi penelitian karena sekolah tersebut memiliki akreditasi sekolah yang sama, yakni A dan belum pernah melaksanakan pembelajaran menulis teks eksposisi dengan strategi Questions into Paragraph (QUIP) dan strategi Information

\section{Charts.}

Adapun waktu penelitian dilaksanakan bulan November 2014. Observasi awal (prasurvei) dilaksanakan pada bulan September 2014 . Sasaran ujicoba instrumen untuk mengukur validitas dan reliabilitas instrumen dilaksanakan di SMP Negeri 9 Yogyakarta pada tanggal 15 November 2014.

Populasi dalam penelitian ini adalah seluruh siswa kelas VII SMP Se-Kota Yogyakarta Tahun Ajaran 2014/2015. Penentuan sampel dalam penelitian ini dilakukan dengan Cluster Random Sampling. Tempat penelitian dilaksanakan di SMP Negeri 1 Yogyakarta dan SMP Negeri 5 Yogyakarta. Penentuan kelas untuk dijadikan kelas kontrol dan kelas eksperimen dilakukan secara random melalui undian.

Hasil undian yang dilakukan untuk menentukan sampel sekolah, diperoleh SMP Negeri 5 sebagai kelas eksperimen 1 dengan kelas terpilih VII 6 dan SMP Negeri 1 sebagai kelas eksperimen 2 dengan kelas terpilih VII H. Setelah diperoleh kelas eksperimen, selanjutnya mengundi SMP sebagai kelas kontrol. Hasil undian menghasilkan SMP Negeri 5 Yogyakarta sebagai kelas kontrol dengan kelas terpilih VII 7. Berikut ini adalah sampel sekolah dan sampel kelas dalam penelitian ini.

Tabel 1. Sampel Penelitian

\begin{tabular}{lccc}
\hline \multicolumn{1}{c}{ Sekolah } & Kelas & $\begin{array}{c}\text { Jumlah } \\
\text { Siswa }\end{array}$ & $\begin{array}{c}\text { Jumlah } \\
\text { Sampel }\end{array}$ \\
\hline SMP Negeri 1 & VII H & 34 & 30 \\
Yogyakarta & VII 6 & 32 & 32 \\
SMP Negeri 5 & VII 7 & 30 & 30 \\
Yogyakarta & 96 & 92 & \\
\hline \multicolumn{1}{c}{ Jumlah } &
\end{tabular}

Instrumen penelitian yang digunakan dalam penelitian ini adalah tes kemampuan menulis teks eksposisi. Instrumen yang digunakan dalam penelitian ini adalah tes buatan sendiri yang disusun berlandaskan teori dan berpedoman pada kurikulum 2013 dan disesuaikan dengan bahan pengajaran.

Pelaksanaan tes dilaksanakan sebanyak dua kali, yakni pretest (sebelum perlakuan) dan posttest (setelah perlakuan). Pemberian perlakuan menggunakan strategi QUIP (Questions into Paragraphs) dan strategi Information 
Charts masing-masing sebanyak enam kali perlakuan.

Validitas yang digunakan dalam penelitian ini adalah validitas isi. Validitas ini melibatkan expert judgement atau orang yang ahli di bidang yang bersangkutan. Instrumen yang divalidasi dalam penelitian ini berupa Rencana Pelaksanaan Pembelajaran (RPP), kisi-kisi soal tes keterampilan menulis teks eksposisi, soal tes keterampilan menulis teks eksposisi, dan rubrik penilaian tes keterampilan menulis teks eksposisi.

Selain validitas isi, validitas lain yang digunakan dalam penelitian ini adalah validitas konstruk. Uji validitas konstruk harus menggunakan data empirik (Nurgiyantoro, Gunawan, dan Marzuki, 2009: 340). Oleh karena itu, instrumen penelitian terlebih dahulu diujicobakan untuk kemudian dianalisis hasilnya.

Berdasarkan hasil analisis menggunakan bantuan komputer program SPSS 17, diperoleh nilai tiap butir rubrik penilaian menulis teks eksposisi, yakni isi tulisan sebesar 1,000, organisasi tulisan 0,772 , kosakata 0,682 , penggunaan bahasa 0,792 , dan mekanik sebesar 0,323 yang berarti lebih besar dari taraf signifikansi 5\% (0,050).

Uji reliabilitas dalam penelitian ini, menggunakan teknik Alpha-Cronbach. Berdasarkan hasil analisis, diperoleh nilai Alpha Cronbach $=0,819$. Angka tersebut, menunjukkan bahwa instrumen yang digunakan dalam penelitian ini memiliki tingkat reliabilitas yang sangat tinggi.

Teknik analisis data yang digunakan dalam penelitian ini dilakukan dengan uji persyaratan analisis, meliputi uji normalitas dan uji homogenitas. Selanjutnya, dilakukan uji hipotesis apabila data yang diuji memenuhi kedua syarat uji normalitas dan homogenitas. Uji hipotesis ini meliputi uji anava dan scheffe.

\section{HASIL DAN PEMBAHASAN}

Pengumpulan data dalam penelitian ini dilakukan dengan tes kemampuan menulis teks eskposisi. Tes dilakukan sebanyak dua kali, yaitu pretest (tes awal) untuk mengetahui kemampuan awal siswa sebelum diberikan perlakuan dan tes akhir (posttest) dilakukan setelah siswa diberikan perlakuan. Tes dilaksanakan pada kelas berbeda, yakni kelas eksperimen yang diberikan perlakuan dengan strategi Questions into Paragraphs dan strategi Information Charts, serta kelas kontrol menggunakan strategi pembelajaran konvensional. Adapun hasil statistik pretest kelas eksperimen1, eksperimen 2, dan kelas kontrol, disajikan dalam tabel 2 berikut.

Tabel 2. Statistik Nilai Pretest Kelas Eksperimen 1, Eksperimen 2, dan Kontrol

\begin{tabular}{lccc}
\hline & $\begin{array}{c}\text { Kelas } \\
\text { Eksperimen } \\
\mathbf{1}\end{array}$ & $\begin{array}{c}\text { Kelas } \\
\text { Eksperimen } \\
\mathbf{2}\end{array}$ & $\begin{array}{c}\text { Kelas } \\
\text { Kontrol }\end{array}$ \\
\hline $\mathrm{N}$ & 32 & 30 & 30 \\
& 0 & 0 & 0 \\
Mean & 66,21 & 64,16 & 66,16 \\
Median & 64,50 & 62,00 & 64,00 \\
Mode & 63,00 & 60,00 & 61,00 \\
SD & 8,42 & 8,43 & 6,79 \\
Min & 50,00 & 50,00 & 58,00 \\
Max & 88,00 & 83,00 & 83,00 \\
Sum & 2119,00 & 1925,00 & 1985,00 \\
\hline
\end{tabular}

\section{Deskripsi Kemampuan Awal \\ Kelas Eksperimen 1}

Kelas eksperimen 1 merupakan kelas yang diberikan perlakuan (treatment) menggunakan strategi Questions into Paragraphs. Siswa pada kelas eksperimen 1 ini, yakni siswa kelas VII 6 SMP Negeri 5 Yogyakarta. Jumlah siswa yang mengikuti pretes pada kelas eksperimen 1, yakni 32 siswa. Pembelajaran menulis teks eksposisi menggunakan strategi (QUIP) Questions into Paragraphs dilaksanakan selama enam kali pertemuan.

Tabel 3. Distribusi Frekuensi Nilai Pretest Kelas Eksperimen 1

\begin{tabular}{ccc}
\hline No. & Kelas Interval & Frekuensi \\
\hline 1. & $80-89$ & 2 \\
2. & $70-79$ & 8 \\
3. & $60-69$ & 17 \\
4. & $50-59$ & 5 \\
\hline & Jumlah & 32 \\
\hline
\end{tabular}

Tabel tersebut, menunjukkan bahwa nilai yang paling sering muncul berada pada interval 3, yakni interval 60-69 sebanyak 17 siswa, dengan besarnya persentase $53,1 \%$. Nilai 
yang paling jarang kemunculannya, berada pada interval 80-89, hanya diperoleh oleh 2 siswa dengan persentase $6,3 \%$.

\section{Kelas Eksperimen 2}

Kelas eksperimen 2 adalah kelas yang menggunakan strategi Information Charts dalam pembelajaran menulis teks eksposisi. Siswa pada kelas eksperimen 2 ini adalah siswa kelas VII H SMP Negeri 1 Yogyakarta. Jumlah siswa yang mengikuti pretest pada kelas eksperimen 2, yakni 30 siswa.

Tabel 4. Distribusi Frekuensi Nilai Pretest Kelas Eksperimen 2

\begin{tabular}{ccc}
\hline No. & Kelas Interval & Frekuensi \\
\hline 1. & $80-89$ & 2 \\
2. & $70-79$ & 5 \\
3. & $60-69$ & 16 \\
4. & $50-59$ & 7 \\
\hline & Jumlah & 30 \\
\hline
\end{tabular}

Tabel tersebut, menunjukkan bahwa frekuensi nilai yang paling sering muncul berada pada interval 60-69, yakni sebesar 16 siswa. Sedangkan, frekuensi nilai yang jarang muncul berada di interval $80-89$, yakni hanya 2 siswa. Tujuh siswa memperoleh nilai pada interval 50-59.

\section{Kelas Kontrol}

Kelas kontrol merupakan kelas yang menggunakan strategi konvensional atau pembelajaran sehari-hari yang biasa dilakukan oleh guru. Siswa pada kelas kontrol ini adalah siswa kelas VII 7 SMP Negeri 5 Yogyakarta. Jumlah siswa yang mengikuti pretest menulis teks eksposisi sebanyak 30 siswa.

Tabel 5. Distribusi Frekuensi Nilai Pretest Kelas Kontrol

\begin{tabular}{ccc}
\hline No. & Kelas Interval & Frekuensi \\
\hline 1. & $80-89$ & 2 \\
2. & $70-79$ & 5 \\
3. & $60-69$ & 22 \\
4. & $50-59$ & 1 \\
\hline & Jumlah & 30 \\
\hline
\end{tabular}

Berdasarkan tabel tersebut, menunjukkan bahwa frekuensi nilai sering muncul berada pada interval 60-69 dengan jumlah frekuensi sebanyak 22 siswa. frekuensi nilai yang jarang kemunculannya ada pada interval 50-59, yakni hanya 1 siswa. Interval nilai 80-89 diperoleh oleh 2 siswa dengan persentase $6,7 \%$ dan interval nilai 70-79 diperoleh oleh 5 siswa dengan persentase $16,7 \%$.

\section{Deskripsi Kemampuan Akhir}

Posttest dilaksanakan setelah dilakukan perlakuan. Perlakuan yang diberikan sebanyak 6 kali. Data posttest yang diperoleh adalah posttest kelas eksperimen 1 yang menggunakan strategi Questions into Paragraphs (QUIP) dan posttest kelas eksperimen 2 yang menggunakan strategi Information Charts dalam pembelajaran menulis teks eksposisi. Berikut tabel statistik posttest kelas eksperimen 1, eksperimen 2, dan kelas kontrol.

Tabel 6. Statistik Nilai Posttest Kelas Eksperimen 1, Eksperimen 2, dan Kontrol

\begin{tabular}{lccc}
\hline & $\begin{array}{c}\text { Kelas } \\
\text { Eksperimen } \\
\mathbf{1}\end{array}$ & $\begin{array}{c}\text { Kelas } \\
\text { Eksperimen } \\
\mathbf{2}\end{array}$ & $\begin{array}{c}\text { Kelas } \\
\text { Kontrol }\end{array}$ \\
\hline $\mathrm{N}$ & 32 & 30 & 30 \\
& 0 & 0 & 0 \\
Mean & 77,00 & 67,83 & 67,60 \\
Median & 73,00 & 68,00 & 64,50 \\
Mode & 73,00 & 68,00 & 61,00 \\
SD & 6,47 & 5,09 & 7,08 \\
Min & 61,00 & 59,00 & 60,00 \\
Max & 87,00 & 80,00 & 83,00 \\
Sum & 2368,00 & 2035,00 & 2028,00 \\
\hline
\end{tabular}

\section{Kelas Eksperimen 1}

Posttest merupakan tes kemampuan akhir menulis teks eksposisi setelah diberikan perlakuan (treatment). Perlakuan pada kelas eksperimen 1 dilakukan sebanyak 6 kali. Jumlah siswa yang mengikuti posttest adalah 32 siswa. 
Tabel 7.Distribusi Frekuensi Nilai Posttest Kelas Eksperimen 1

\begin{tabular}{ccc}
\hline No. & Kelas Interval & Frekuensi \\
\hline 1. & $80-89$ & 6 \\
2. & $70-79$ & 19 \\
3. & $60-69$ & 7 \\
4. & $50-59$ & 0 \\
\hline & Jumlah & 32 \\
\hline
\end{tabular}

Berdasarkan tabel tersebut, menunjukkan bahwa frekuensi nilai yang paling sering muncul berada pada interval 70-79, yakni dicapai oleh 19 siswa dengan persentase 59,4\%. Siswa yang mencapai nilai pada interval 80-89 ada enam siswa dengan persentase $18,7 \%$. Tujuh siswa memperoleh nilai pada interval 60-69 dengan persentase $21,9 \%$. Pada interval 50-59, tidak ada siswa yang memperoleh nilai pada interval tersebut.

\section{Kelas Eksperimen 2}

Posttest kelas eksperimen 2 yang menggunakan strategi Information Charts dilaksanakan pada tanggal 29 November 2014. Posttest dilakukan untuk mengetahui kemampuan akhir siswa setelah dilakukan perlakuan dengan menggunakan strategi Information Charts.

Tabel 8.Distribusi Frekuensi Nilai Posttest Kelas Eksperimen 2

\begin{tabular}{ccc}
\hline No. & Kelas Interval & Frekuensi \\
\hline 1. & $80-89$ & 1 \\
2. & $70-79$ & 9 \\
3. & $60-69$ & 19 \\
4. & $50-59$ & 1 \\
\hline \multicolumn{2}{c}{ Jumlah } & 30 \\
\hline
\end{tabular}

Berdasarkan tabel tersebut, dapat diketahui bahwa frekuensi nilai yang kemunculannya sering berada pada interval 60-69, yakni dicapai oleh 19 siswa dengan persentase $63,3 \%$. Interval nilai 70-79 dicapai oleh 9 siswa dengan persentase $30 \%$. Interval nilai yang jarang kemunculannya adalah interval 50-59 dan 80-89 yang dicapai hanya oleh 1 siswa dengan persentase masing-masing 3,3\%.

\section{Kelas Kontrol}

Posttest kelas kontrol dilaksanakan pada tanggal 29 November 2014. Siswa yang menjadi kelas kontrol adalah siswa kelas VII 7 SMP Negeri 5 Yogyakarta. Berikut disajikan tebl distribusi frekuensi Posttest kelas kontrol.

Tabel 9.Distribusi Frekuensi Nilai Posttest Kelas Kontrol

\begin{tabular}{ccc}
\hline No. & Kelas Interval & Frekuensi \\
\hline 1. & $80-89$ & 2 \\
2. & $70-79$ & 8 \\
3. & $60-69$ & 20 \\
4. & $50-59$ & 0 \\
\hline & Jumlah & 30
\end{tabular}

Dari tabel tersebut, menunjukkan bahwa interval nilai 60-69 diperoleh oleh 20 siswa dengan persentase $66.7 \%$. Interval nilai 70-79 dicapai oleh 8 siswa dan interval 80-89 dicapai oleh 2 siswa dengan persentase sebesar $6.6 \%$.

\section{Pengujian Hipotesis}

Pengujian hipotesis dalam penelitian ini menggunakan uji anava dilanjutkan dengan uji scheffe. Pengujian ini dilaksanakan setelah terpenuhinya uji normalitas dan homogenitas varian. Adapun hipotesis yang diuji adalah sebagai berikut. Pertama, terdapat perbedaan yang signifikan antara keterampilan menulis teks eksposisi siswa yang diajar menggunakan strategi QUIP (Questions into Paragrahps) dengan siswa yang tidak diajar menggunakan strategi QUIP (Questions into Paragrahps). Kedua, penggunaan strategi QUIP (Questions into Paragrahps) dalam pembelajaran menulis teks eksposisi lebih efektif apabila dibandingkan dengan pembelajaran menulis teks eksposisi tanpa strategi QUIP (Questions into Paragrahps). Ketiga, terdapat perbedaan yang signifikan antara keterampilan menulis teks eksposisi siswa yang diajar menggunakan strategi Information Charts dengan siswa yang tidak diajar menggunakan strategi Information Charts.

Keempat, penggunaan strategi Information Charts dalam pembelajaran menulis teks eksposisi lebih efektif apabila dibandingkan dengan pembelajaran menulis teks eksposisi 
tanpa strategi Information Charts. Kelima, terdapat perbedaan yang signifikan antara keterampilan menulis teks eksposisi siswa yang diajar menggunakan strategi QUIP (Questions into Paragraphs) dengan siswa yang diajar menggunakan strategi Information Charts. Keenam, penggunaan strategi QUIP (Questions into Paragraphs) lebih efektif apabila dibandingkan dengan strategi Information Charts dan strategi konvensional dalam pembelajaran menulis teks eksposisi.

Pengujian hipotesis tersebut dilakukan dengan uji anava dilanjutkan dengan uji scheffe yang dibantu dengan program SPSS 17.0. Ringkasan hasil uji anava disajikan dalam tabel 10.

Berdasarkan tabel tersebut, secara keseluruhan diketahui bahwa nilai F sebesar 10.458 dengan signifikansi 0.000. Dengan demikian, terdapat perbedaan keefektifan yang signifikan antara strategi QUIP (Questions into Paragraphs), information charts, dan konvensional dalam pembelajaran menulis teks eksposisi siswa kelas VII SMP Se-Kota Yogyakarta.

\section{Uji Hipotesis Pertama}

Hipotesis yang diajukan dalam penelitian ini adalah hipotesis alternatif $\left(\mathrm{H}_{\mathrm{a}}\right)$ terdapat perbedaan yang signifikan antara keterampilan menulis teks eksposisi siswa yang diajar menggunakan strategi QUIP (Questions into Paragrahps) dengan siswa yang tidak diajar menggunakan strategi QUIP (Questions into Paragrahps).
Berdasarkan hasil pengujian hipotesis melalui uji anava satu jalan menunjukkan bukti bahwa terdapat perbedaan yang signifikan antara keterampilan menulis teks eksposisi siswa yang diajar menggunakan strategi QUIP (Questions into Paragrahps) dengan siswa yang tidak diajar menggunakan strategi QUIP (Questions into Paragrahps). Hal tersebut, dapat dilihat dari nilai Sig (2-tailed) 0,000 yang lebih kecil dari 0,050 (taraf signifikansi 5\%). Dengan demikian, disimpulkan bahwa pemberian perlakuan dengan penerapan strategi QUIP (Questions into Paragraphs) di kelas eksperimen 1, menyebabkan adanya perbedaan hasil akhir pada dua kelas tersebut.

\section{Uji Hipotesis Kedua}

Hipotesis yang diajukan dalam penelitian ini adalah hipotesis alternatif $\left(\mathrm{H}_{\mathrm{a}}\right)$ penggunaan strategi QUIP (Questions into Paragrahps) dalam pembelajaran menulis teks eksposisi lebih efektif apabila dibandingkan dengan pembelajaran menulis teks eksposisi tanpa strategi QUIP (Questions into Paragrahps).

Dari hasil perhitungan, diperoleh peningkatan nilai kelas eksperimen sebesar 7,79 dan peningkatan nilai kelas kontrol 1,44. Hal itu, menunjukkan bahwa peningkatan nilai kelas eksperimen 1 lebih besar dari peningkatan nilai kelas kontrol. Dilihat dari perbedaan mean posttest kelas eksperimen 1 lebih besar dari mean posttest kelas kontrol, yakni 74,00 > 67,60. Dengan demikian, disimpulkan bahwa penggu-

Tabel 10. Ringkasan Hasil Uji Anava Posttest

\begin{tabular}{lccccc}
\hline & Sum of Squares & df & Mean Square & F & Sig. \\
\hline Between Groups & 824,753 & 2 & 412,376 & 10,458 & \multirow{2}{*}{000} \\
Within Groups & 3509,367 & 89 & 39,431 & & \\
\hline Total & 4334,120 & 91 & & & \\
\hline
\end{tabular}

Tabel 11. Ringkasan Hasil Uji Scheffe Posttest

\begin{tabular}{clcc}
\hline \multicolumn{1}{c}{ (I) Kelompok } & \multicolumn{1}{c}{$(\mathrm{J})$ Kelompok } & Mean Difference (I-J) & Sig. \\
\hline \multirow{2}{*}{ Strategi QUIP } & Strategi Information Charts & $6,16667^{*}$ &, 001 \\
& Tanpa Strategi & $6,40000^{*}$ &, 001 \\
\multirow{2}{*}{ Strategi Information Charts } & Strategi QUIP & $-6,16667^{*}$ &, 001 \\
& Tanpa Strategi &, 23333 &, 990 \\
Tanpa Strategi & Strategi QUIP & $-6,40000^{*}$ &, 001 \\
& Strategi Information Charts &,- 23333 &, 990 \\
\hline
\end{tabular}


naan strategi QUIP (Questions into Paragrahps) dalam pembelajaran menulis teks eksposisi lebih efektif apabila dibandingkan dengan pembelajaran menulis teks eksposisi tanpa strategi QUIP (Questions into Paragrahps).

Tabel 12. Peningkatan Nilai Pretest dan Posttest

\begin{tabular}{lcc}
\hline \multicolumn{1}{c}{ Kelas } & Mean & $\begin{array}{c}\text { Peningkatan } \\
\text { Nilai }\end{array}$ \\
\hline $\begin{array}{l}\text { Pretest Kelas } \\
\text { Eksperimen 1 }\end{array}$ & 66,21 & \\
Posttest Kelas & 74,00 & 7,79 \\
Eksperimen 1 & \\
Pretest Kelas Kontrol & 66,16 & \\
Posttest Kelas Kontrol & 67,60 & 1,44 \\
\hline
\end{tabular}

Uji Hipotesis Ketiga

Hipotesis yang diajukan dalam penelitian ini adalah hipotesis alternatif $\left(\mathrm{H}_{\mathrm{a}}\right)$ yang berbunyi terdapat perbedaan yang signifikan antara keterampilan menulis teks eksposisi siswa yang diajar menggunakan strategi Information Charts dengan siswa yang tidak diajar menggunakan strategi Information Charts. Berdasarkan hasil uji anava diperoleh nilai $\mathrm{F}$ sebesar 10,458 dengan signifikansi 0,000. Dengan demikian, dari hasil uji anava nilai signifikansi yang diperoleh lebih kecil dari 0,050 sehingga $\mathrm{H}_{\mathrm{a}}$ yang berbunyi terdapat perbedaan yang signifikan antara keterampilan menulis teks eksposisi siswa yang diajar menggunakan strategi Information Charts dengan siswa yang tidak diajar menggunakan strategi Information Charts diterima.

\section{Uji Hipotesis Keempat}

Hipotesis yang diajukan dalam penelitian ini adalah hipotesis alternatif $\left(\mathrm{H}_{\mathrm{a}}\right)$ penggunaan strategi Information Charts dalam pembelajaran menulis teks eksposisi lebih efektif apabila dibandingkan dengan pembelajaran menulis teks eksposisi tanpa strategi Information Charts. Berikut disajikan tabel peningkatan nilai Pretest dan Posttest kelas eksperimen 2 dan kelas kontrol.
Tabel 13. Peningkatan Nilai Pretest dan Posttest

\begin{tabular}{lcc}
\hline \multicolumn{1}{c}{ Kelas } & Mean & $\begin{array}{c}\text { Peningkatan } \\
\text { Nilai }\end{array}$ \\
\hline $\begin{array}{l}\text { Pretest } \text { Kelas } \\
\text { Eksperimen 2 }\end{array}$ & 64,16 & \\
$\begin{array}{l}\text { Posttest } \text { Kelas } \\
\text { Eksperimen 2 }\end{array}$ & 67,83 & 3,67 \\
Pretest Kelas Kontrol & 66,16 & \\
Posttest Kelas Kontrol & 67,60 & 1,44 \\
\hline
\end{tabular}

Berdasarkan hasil penghitungan, diperoleh peningkatan nilai dari pretest kelas eksperimen 2 ke posttest kelas eksperimen 2 sebesar 3,67 dan peningkatan nilai kelas kontrol 1,44. Mean posttest kelas eksperimen 2 dan mean posttest kelas kontrol sebesar 67,83 dan 67,60, sehingga mean posttest kelas eksperimen 2 lebih besar daripada mean postest kelas kontrol. Dengan demikian, dilihat dari mean posttestnya, disimpulkan bahwa penggunaan strategi Information Charts dalam pembelajaran menulis teks eksposisi lebih efektif apabila dibandingkan dengan pembelajaran menulis teks eksposisi tanpa strategi Information Charts.

\section{Uji Hipotesis Kelima}

Hipotesis yang diajukan dalam penelitian ini adalah hipotesis alternatif $\left(\mathrm{H}_{\mathrm{a}}\right)$ terdapat perbedaan yang signifikan antara keterampilan menulis teks eksposisi siswa yang diajar menggunakan strategi QUIP (Questions into Paragraphs) dengan siswa yang diajar menggunakan strategi Information Charts. Sesuai dengan hasil analisis yang telah dilakukan, baik berdasarkan hasil uji anava, nilai Sig (2-tailed) posttest kelas eksperimen 1 dan kelas eksperimen $20,000<0,050$ dengan nilai $\mathrm{F}=10,458$ sehingga $\mathrm{H}_{\mathrm{a}}$ yang berbunyi terdapat perbedaan yang signifikan antara keterampilan menulis teks eksposisi siswa yang diajar menggunakan strategi QUIP (Questions into Paragraphs) dengan siswa yang diajar menggunakan strategi Information Charts diterima.

\section{Uji Hipotesis Keenam}

Hipotesis keenam yang diajukan dalam penelitian ini adalah hipotesis alternatif $\left(\mathrm{H}_{\mathrm{a}}\right)$ penggunaan strategi QUIP (Questions into Paragraphs) lebih efektif apabila dibandingkan 
dengan strategi Information Charts dan strategi konvensional dalam pembelajaran menulis teks eksposisi. Berdasarkan hasil uji scheffe yang telah dilakukan, dilihat dari mean differencenya, menunjukkan adanya tingkat keefektifan yang berbeda antara strategi pembelajaran QUIP (Question into Paragraphs), strategi Information Charts, dan tanpa strategi pembelajaran. Strategi yang paling efektif digunakan dalam pembelajaran menulis teks eksposisi adalah strategi QUIP (Questions into Paragraphs), kemudian diikuti strategi Information Charts, dan tanpa strategi pembelajaran.

\section{Pembahasan}

Bagian ini memaparkan hasil-hasil penelitian sebagai berikut. Pertama, terdapat perbedaan yang signifikan antara keterampilan menulis teks eksposisi siswa yang diajar menggunakan strategi QUIP (Questions into Paragrahps) dengan siswa yang tidak diajar menggunakan strategi QUIP (Questions into Paragrahps). Strategi QUIP (Questions into Paragraphs) merupakan strategi yang memiliki langkah-langkah pembelajaran yakni, interview grid (wawancara jaringan), outline (kerangka), dan paragraphs (paragraf).

Berdasarkan hasil pengujian hipotesis melalui uji anava satu jalan menunjukkan bukti bahwa terdapat perbedaan yang signifikan antara keterampilan menulis teks eksposisi siswa yang diajar menggunakan strategi QUIP (Questions into Paragrahps) dengan siswa yang tidak diajar menggunakan strategi QUIP (Questions into Paragrahps). Hal tersebut, dapat dilihat dari nilai Sig (2-tailed) 0,000 yang lebih kecil dari 0,050 (taraf signifikansi 5\%). Dengan demikian, disimpulkan bahwa pemberian perlakuan dengan penerapan strategi QUIP (Questions into Paragraphs) di kelas eksperimen 1, menyebabkan adanya perbedaan hasil akhir pada dua kelas tersebut.

Kedua, penggunaan strategi QUIP (Questions into Paragrahps) dalam pembelajaran menulis teks eksposisi lebih efektif apabila dibandingkan dengan pembelajaran menulis teks eksposisi tanpa strategi QUIP. Strategi QUIP (Questions into Paragraphs) merupakan strategi yang dikembangkan untuk membantu siswa dalam membaca dan menulis teks eks- positori (Mc.Laughlin, 1987: 651). Sesuai dengan pendapat tersebut, strategi ini terbukti efektif digunakan dalam pembelajaran menulis teks eksposisi. Siswa sangat antusias dan aktif dalam melaksanakan pembelajaran menggunakan strategi ini.

Berdasarkan hasil pengujian yang telah dilakukan sebelumnya, diketahui bahwa rerata nilai kelas eksperimen setelah diberikan perlakuan lebih tinggi dibandingkan kelas kontrol. Meskipun kedua kelas tersebut mengalami peningkatan rerata nilai, tetapi nilai rerata kelas eksperimen 1 lebih tinggi dibandingkan kelas kontrol. Peningkatan nilai pretest ke posttest kelas eksperimen 1 mencapai 7,79, sedangkan kelas kontrol mengalami peningkatan dari pretest menuju posttest 1,44 sehingga pemberian perlakuan atau penggunaan strategi QUIP (Questions into Paragrahps) efektif digunakan dalam pembelajaran menulis teks eksposisi siswa kelas VII SMP Se-Kota Yogyakarta.

Penggunaan strategi QUIP (Questions into Paragrahps) efektif digunakan dalam pembelajaran menulis teks eksposisi dikarenakan strategi ini memiliki kelebihan, yakni mengunakan format wawancara. Selain siswa melakukan wawancara, siswa juga dapat mencari informasi melalui referensi-referensi dari buku. Hal ini, membuat siswa memperoleh data dan faktafakta yang lebih rinci dan akurat.

Ketiga, terdapat perbedaan yang signifikan antara keterampilan menulis teks eksposisi siswa yang diajar menggunakan strategi Information Charts dengan siswa yang tidak diajar menggunakan strategi Information Charts. Langkah dalam pembelajaran menulis teks eksposisi dengan strategi Information Charts adalah siswa memilih topik tulisan yang akan dikembangkan dalam penulisan teks eksposisi. Selanjutnya, siswa diberikan format untuk menyelesaikan dan menunjukkan pengetahuan yang mereka ketahui. Siswa diberikan waktu untuk memastikan informasi apa yang perlu diketahui dan subtopik apa yang akan ditulis. Kemudian, siswa mencari dan menemukan buku-buku dan artikel tentang subtopik yang akan mereka tulis. Siswa melengkapi format tabel yang diberikan guru. Terakhir, siswa mulai menulis teks eksposisi dengan berpedoman pada tabel yang sudah dilengkapi. 
Berdasarkan hasil pengujian hipotesis melalui uji anava satu jalan menunjukkan bukti bahwa tidak terdapat perbedaan yang signifikan antara keterampilan menulis teks eksposisi siswa yang diajar menggunakan strategi Information Charts dengan siswa yang tidak diajar menggunakan strategi Information Charts. Hal ini, dapat dilihat dari hasil uji anava nilai $\mathrm{F}=10,458$ dengan Sig (2-tailed) postes kelas eksperimen 2 dan kelas kontrol 0,000.

Dengan demikian, hasil uji anava satu jalan menunjukkan nilai signifikansi yang lebih besar dari 0,050 (taraf signifikansi 5\%). Jadi, disimpulkan bahwa pemberian perlakuan dengan penerapan strategi Information Charts di kelas eksperimen 2 menyebabkan adanya perbedaan yang signifikan antara keterampilan menulis teks eksposisi siswa yang diajar menggunakan strategi Information Charts dengan siswa yang tidak diajar menggunakan strategi Information Charts.

Keempat, penggunaan strategi Information Charts dalam pembelajaran menulis teks eksposisi lebih efektif apabila dibandingkan dengan pembelajaran menulis teks eksposisi tanpa strategi Information Charts. Hoffman (1992) dalam Randall (1996: 537) mengembangkan tabel informasi sebagai strategi untuk menginstruksikan secara langsung dari keterampilan berpikir kritis melalui keaksaraan. Penggunaan strategi Information Charts ini, tidak begitu menarik perhatian siswa. Meskipun demikian, pembelajaran tetap berjalan dengan lancar. Siswa mengerjakan tugas yang diberikan oleh guru dan mencari sumber referensi dari buku sesuai dengan topik dan tema yang telah ditentukan sebelumnya.

Berdasarkan hasil pengujian yang telah dilakukan, diketahui bahwa rerata nilai posttest kelas eksperimen 2 lebih besar dari rerata kelas kontrol. Terdapat peningkatan nilai rerata pretest ke postest kelas eksperimen 2 sebesar 3,67, sedangkan kelas kontrol mengalami peningkatan dari pretest menuju posttest hanya 1,44 . Hal ini, menunjukkan pemberian perlakuan atau penggunaan strategi Information Charts lebih efektif apabila dibandingkan dengan pembelajaran menulis teks eksposisi tanpa strategi Information Charts. Penggunaan strategi Information Charts efektif digunakan dalam pembelajaran menulis teks eksposisi karena strategi ini menggunakan tabel yang memudahkan siswa untuk mengorganisasi informasi.

Kelima, terdapat perbedaan yang signifikan antara keterampilan menulis teks eksposisi siswa yang diajar menggunakan strategi QUIP (Questions into Paragraphs) dengan siswa yang diajar menggunakan strategi Information Charts. Strategi QUIP (Questions into Paragraphs) merupakan strategi yang dikembangkan untuk membantu siswa dalam membaca dan menulis teks ekspositori.

Berdasarkan hasil pengujian hipotesis melalui uji anava satu jalan menunjukkan bukti bahwa terdapat perbedaan yang signifikan antara keterampilan menulis teks eksposisi siswa yang diajar menggunakan strategi QUIP (Questions into Paragrahps) dengan siswa yang diajar menggunakan strategi Information Charts. Hal tersebut, dapat dilihat dari nilai F sebesar 10,458 dengan signifikansi 0,000. Dengan demikian, disimpulkan bahwa pemberian perlakuan dengan penerapan strategi QUIP (Questions into Paragraphs) di kelas eksperimen 1 dan pemberian perlakuan dengan menggunakan strategi Information Charts menyebabkan adanya perbedaan yang signifikan hasil akhir pada dua kelas tersebut.

Adanya perbedaan ini dikarenakan strategi pembelajaran QUIP (Questions into Paragraphs) memiliki kelebihan dibandingkan dengan strategi information charts. Hal ini disebabkan strategi pembelajaran QUIP (Questions into Paragraphs) menggunakan format wawancara. Selain siswa melakukan wawancara, siswa juga dapat mencari informasi melalui referensi-referensi dari buku. Hal ini, membuat siswa memperoleh data dan fakta-fakta yang lebih rinci dan akurat. Sedangkan, pada strategi information charts sumber yang digunakan siswa hanya diperoleh melalui sumber referensi berupa buku atau artikel

Keenam, penggunaan strategi QUIP (Questions into Paragraphs) lebih efektif apabila dibandingkan dengan strategi Information Charts dan strategi konvensional dalam pembelajaran menulis teks eksposisi. Berdasarkan hasil uji scheffe yang telah dilakukan, dilihat dari mean difference-nya menunjukkan adanya tingkat keefektifan yang berbeda antara strategi 
pembelajaran QUIP (Question into Paragraphs), strategi Information Charts, dan tanpa strategi pembelajaran. Nilai mean difference tersebut adalah 6,166 antara strategi QUIP (Questions into Paragraphs) dengan strategi Information Charts. Mean difference 6,400 antara strategi QUIP (Questions into Paragraphs) dengan tanpa strategi pembelajaran. Nilai mean difference 0,233 antara strategi Information Charts dan tanpa strategi pembelajaran.

Sesuai dengan penjelasan di atas, strategi pembelajaran yang paling efektif digunakan dalam menulis teks eksposisi adalah strategi QUIP (Questions into Paragraphs), kemudian diikuti strategi Information Charts, dan tanpa strategi pembelajaran. Namun, dilihat dari signifikansinya, ada yang tidak signifikan perbedaannya antara strategi-strategi tersebut, yakni strategi Information Charts dan strategi konvensional dengan taraf signifikansi 0,990> 0,050. Dengan demikian, strategi QUIP (Questions into Paragraphs) merupakan strategi yang paling efektif digunakan dalam pembelajaran menulis teks eksposisi siswa kelas VII SMP Se-Kota Yogyakarta.

Strategi pembelajaran QUIP (Questions into Paragraphs) lebih efektif dibandingkan strategi information charts dan strategi konvensional dikarenakan sumber referensi yang dipakai dalam strategi pembelajaran QUIP (Questions into Paragraphs) lebih lengkap dan akurat, yakni dengan menggunakan format wawancara. Selain siswa melakukan wawancara, siswa juga dapat mencari informasi melalui referensi-referensi dari buku. Hal ini, membuat siswa memperoleh data dan fakta-fakta yang lebih rinci dan akurat. Sedangkan, pada strategi information charts sumber yang digunakan siswa hanya diperoleh melalui sumber referensi berupa buku atau artikel dan pada strategi konvensional siswa tidak menggunakan referensi apapun dalam mencari sumber informasi dalam kaitannya dengan pembelajaran menulis teks eksposisi.

\section{SIMPULAN}

Berdasarkan pembahasan tersebut, disimpulkan terdapat perbedaan yang signifikan antara keterampilan menulis teks eksposisi siswa yang diajar menggunakan strategi QUIP(Questions into Paragrahps) dengan siswa yang tidak diajar menggunakan strategi QUIP (Questions into Paragrahps). Penggunaan strategi QUIP (Questions into Paragrahps) dalam pembelajaran menulis teks eksposisi lebih efektif apabila dibandingkan dengan pembelajaran menulis teks eksposisi tanpa strategi QUIP (Questions into Paragrahps). Terdapat perbedaan yang signifikan antara keterampilan menulis teks eksposisi siswa yang diajar menggunakan strategi Information Charts dengan siswa yang tidak diajar menggunakan strategi Information Charts. Penggunaan strategi Information Charts dalam pembelajaran menulis teks eksposisi lebih efektif apabila dibandingkan dengan pembelajaran menulis teks eksposisi tanpa strategi Information Charts.

Selain itu, terdapat perbedaan yang signifikan antara keterampilan menulis teks eksposisi siswa yang diajar menggunakan strategi QUIP (Questions into Paragraphs) dengan siswa yang diajar menggunakan strategi Information Charts. Penggunaan strategi QUIP (Questions into Paragraphs) lebih efektif apabila dibandingkan dengan strategi information charts dan strategi konvensional dalam pembelajaran menulis teks eksposisi.

\section{DAFTAR PUSTAKA}

Nurgiyantoro, Burhan, Gunawan, \& Marzuki. 2009. Statistik terapan untuk penelitian ilmu-ilmu sosial. Yogyakarta: Gadjah Mada University Press.

Hoffman, J.V. 1992. Critical reading / thinking accros the curriculum: using i-charts to support learning. Language Arts. 69, 121-127.

Efendi, Joni Lis. 2011. Mengapa pemuda kita tidak bisa menulis. Diambil pada tanggal 26 Agustus 2014, dari http:// edukasi.kompasiana.com/2011/07/23/ mengapa-pemuda-kita-tidak-bisamenulis-382140.html

Kompas. 2011. Tradisi menulis lebih rendah daripada minat baca. Diambil pada 26 Agustus 2014, dari http://edukasi.kompas.com/read/2011/11/23/10491011/ Tradisi.Menulis.Lebih.Rendah.daripada.Minat.Baca 
McLaughlin, M. 1987. QuIP: A writing strategy to improve comprehension of expository structure. The Reading Teacher. 650-654.

Damayanti, Rini 2010. Keefektifan penggunaan siaran $T V$ dan radio dalam pembelaja- ran keterampilan menulis berita peserta didik SMP. Tesis magister, Universitas Negeri Yogyakarta.

Zainurrahman. 2011. Menulis dari teori hingga praktik (penawar racun plagiarisme). Bandung: Alfabeta. 